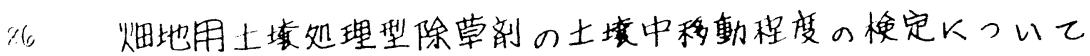

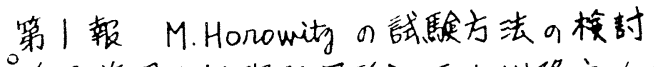

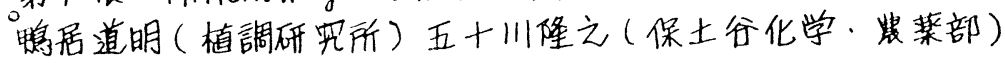

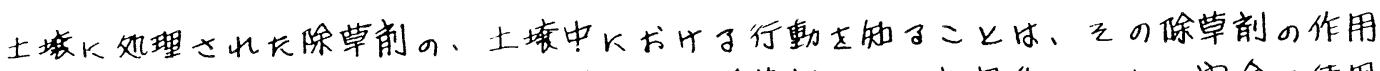

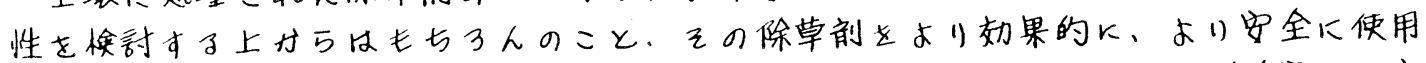
する波に久くことのできかいことである。演者等は、M.Honowitg(1966)が考棵しK方

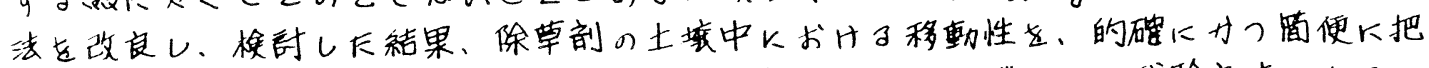
握ですると共火、種々の变動要因の解明にも㐫用することガできる武験方法であるこ とガ巾オっ长ので颇告する。

\title{
工实验材料お゙ば方法
}

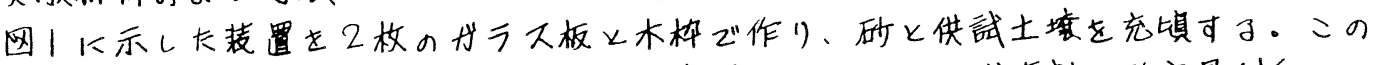

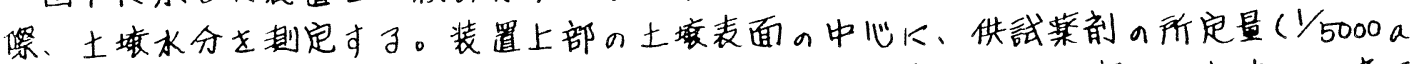

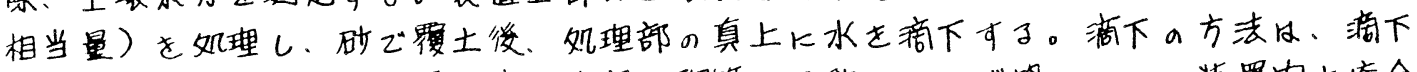

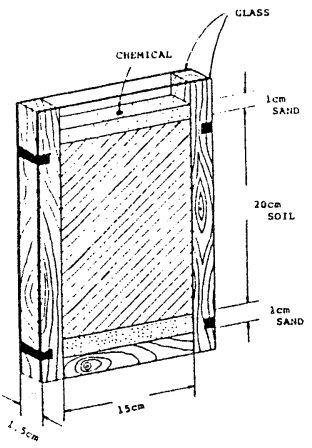

四 1 量、滴下速度の調䬦が可能なものガ望ましい、装置内土坮全

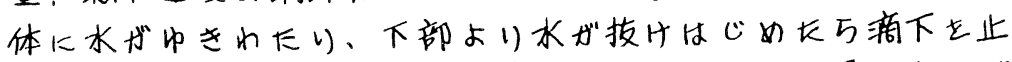
め、上部下格を入れ乙固定する。この時摘下水星と摘下時 間を記録しておく。装置を水平火して片方のガラス板を取り はずし、土烄表面下供試植物の種子をまんべんなく播穞し、 軽く鎮圧後、種子ガ隐山子程度下細研で覆土し、温空内で育 成吉子。供試植物は、供試菜剂に对して感受性ボ高く丹つ、 種子の細力はものを選定する。(メヒシバ・ヤオビ工等)

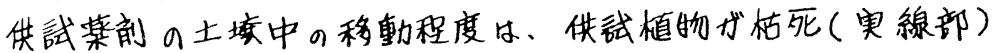
もしくは、生充抑制を受け长部分(点部分)までの、观理部 分らの距離・形状・面糟をもって判断する。

正果验、烟地用除草剂の土壤中における移動性について。

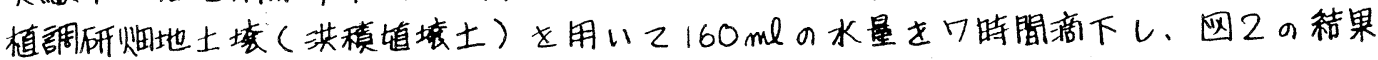
文得下。除草削の種類により移動性は、ほとんど移動しはいもの、模移動は大きいオ゙

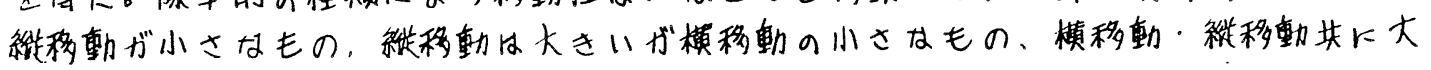
きなもの、ガあることが明らがとなった。

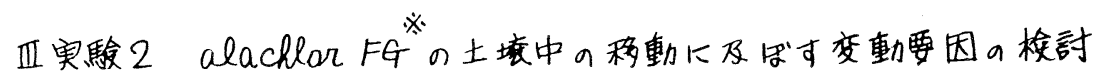

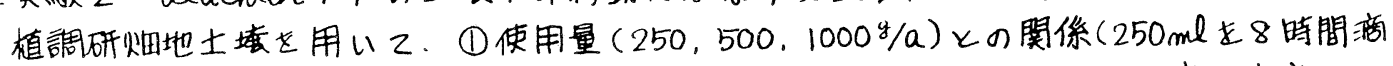

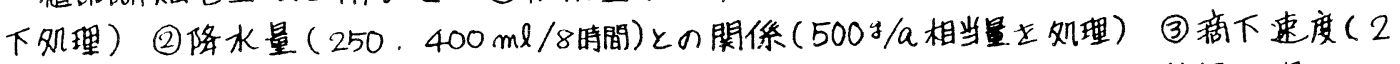

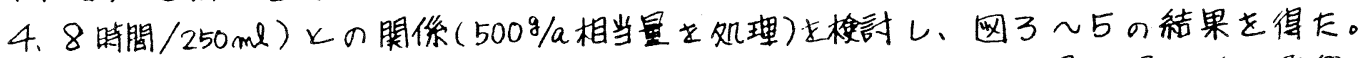
alachlar F9の土境中の移動性は、椎討した了要因の中では降水量下最も強く影留され ることガ明らカとなった。

注必 FG…日植調協会で細粒削として扱った除草削についてだけ表示した。 

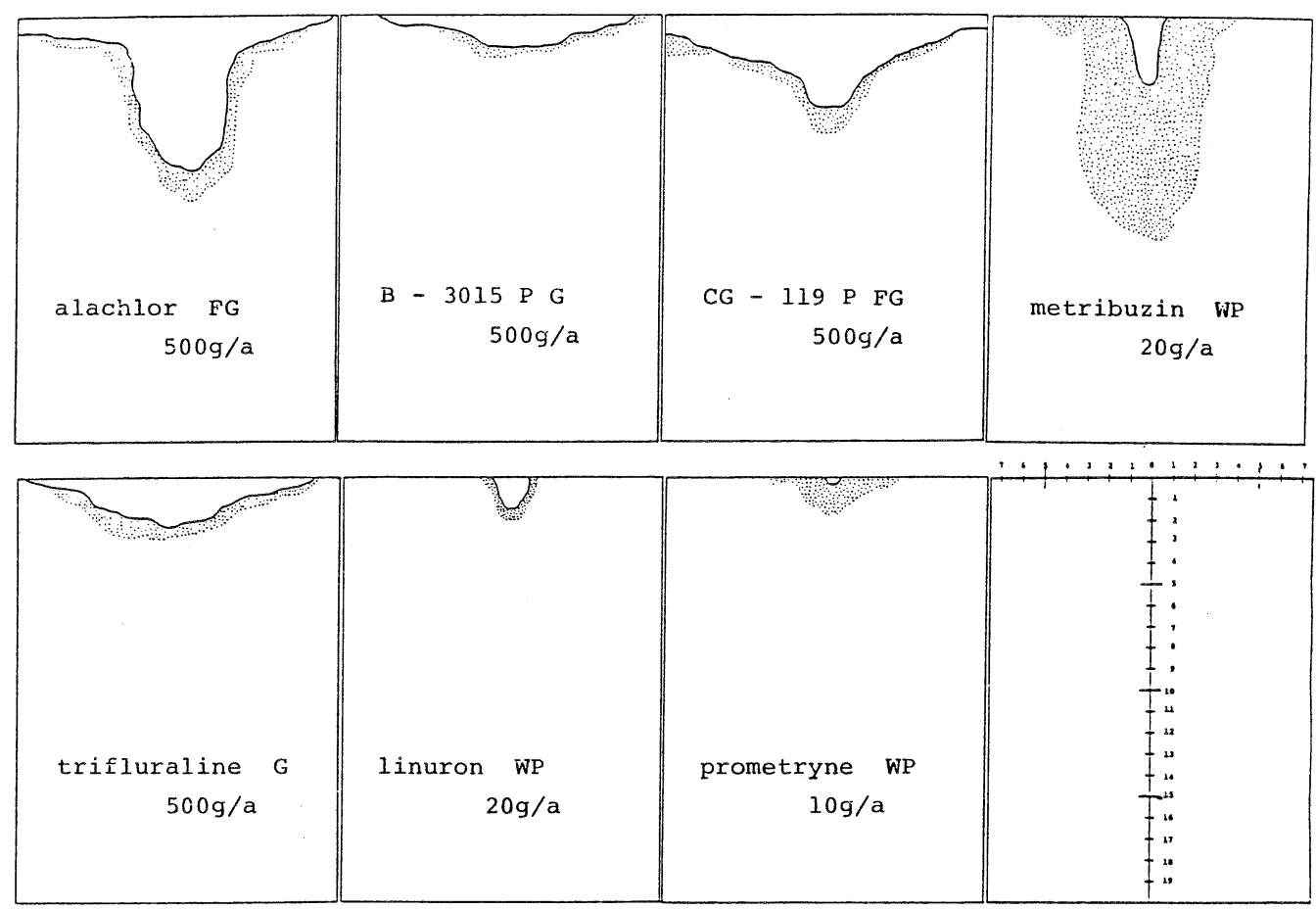

四2畑地用除草剖の土境中の移動性( $160 \mathrm{ml} / 8$ 時間)
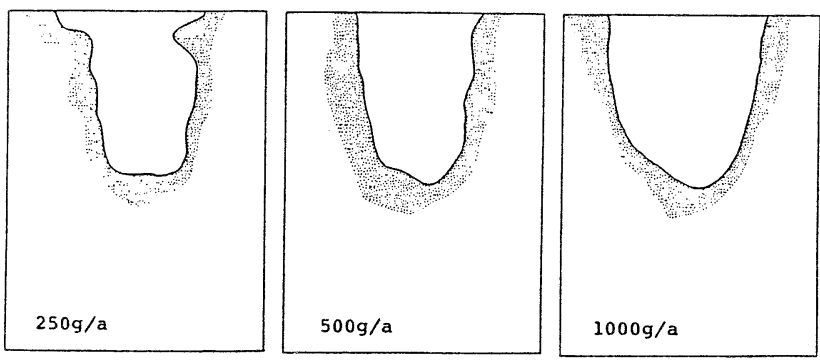

四3 alachlor FGの移動性と使用量の関保 ( $250 \mathrm{ml} / 8$ 时间)
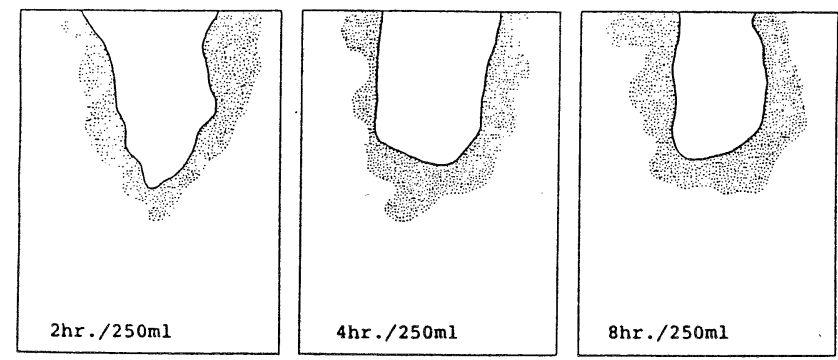

四5 alachlorFGの移動性と滴下速度の関係

$$
(500 \mathrm{~g} / \mathrm{a})
$$

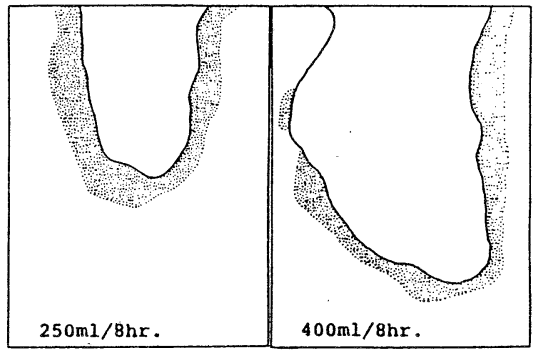

四4 alachlor任の移䡃性と降水量口関係 ( $500 \mathrm{~g} / \mathrm{a}$ ) 


\section{一前宣正、近内誠登、人見浩、竹松抬夫( 㒵都宫大、贯)}

界面活性剂は広籍な分野に利用、れている重要な盗栈の一フである。除草剂の分野 ぐも。製剂上の目的である水和性、乳化性、㧓散性、分散性、崩壃性など諸性算の賦

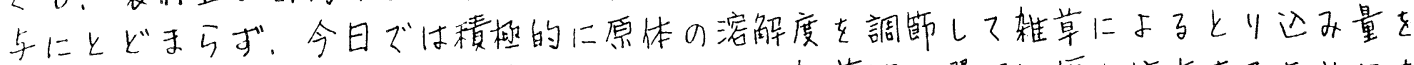

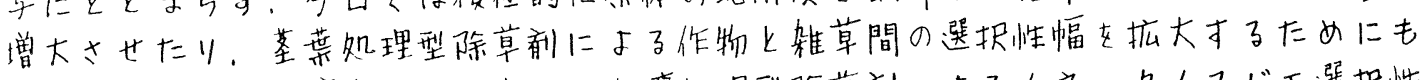

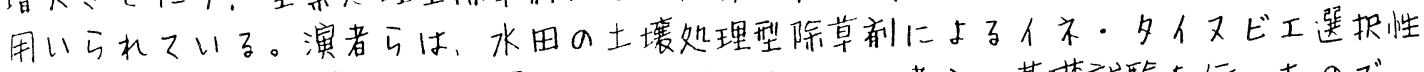
の幅についても界面活性剂が関与するのではないかと考え、基礎試駰を行ったので、 光の結果女報告する。

\section{实唤方法}

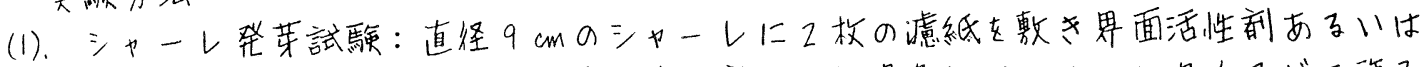

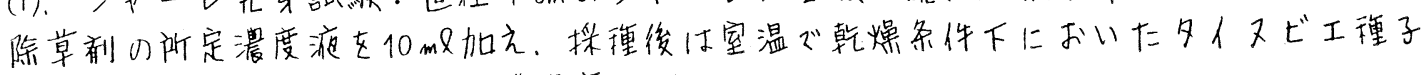
を20粒ブつ置床し、20日後に発牙率を調べた。

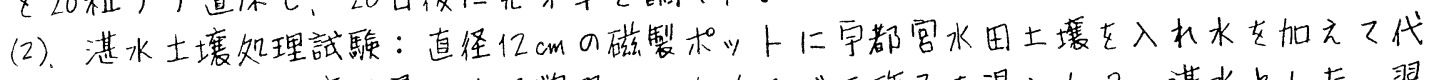

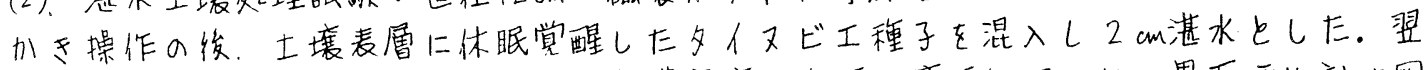
日。道与に除草剂上界面活性剂の所定濃度渡を水面上滴下処理した。界面活性剂は四 ろでイネ・タイスビ工間の遥択性幅が最も広かつたものを用いた。処理了日後に催牙 イネ(アキニシキ)を播き、好理15日役に生充状况を観察調查した。

实験結果

一般に界面活性剂之法ののは湛水条件下で如理しても除草効果を示さないものが多い。 当こで、あらか心゙め休眠が完全に党睲していない夕人又ビエ種子に影餢のあることを

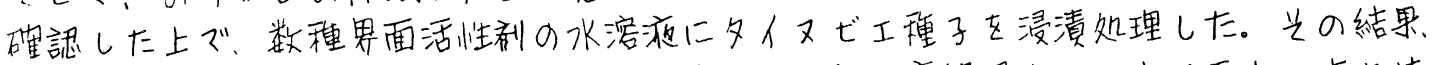
アルキルフェールエテレンオキサイド仏加型（N-1）と高級アルコールエテレンオキサ

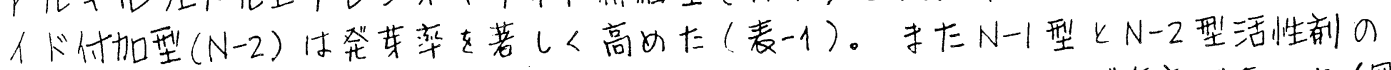

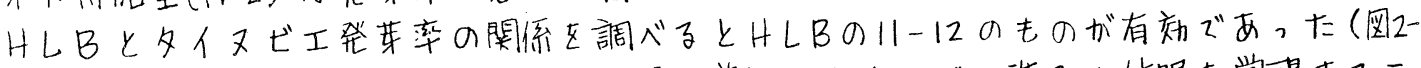
[A])。一方、既知のジ7ェニルエーテル系除草剂がタイマビエ程子の休眼を党醒する二 とは周知のことで四1にも確認、れた。この系統除草刹の中於らォキサジアゾンをと リあげて、上述したN-1型とNー2 型活性剂との組合わせでタイマビエの発牙率におよ ぼす影龧を調べたところ。メはりHしBが10ー11程度の活性刹に活性の高いことが判明 した(四2ー [B])。×らに興味あることにオキサジアゾンによるイネ・タイスビエ間の 望択性幅がNー型活性刹の浠加によってどのように变化するかを調べた結果（四了）、 これまでとは䔔つてHLBの13程度のものに迤択性幅の最も広く発現することがれか フた。外上の結果に基いる䒠際の国場を想定した好理の結果が表2である。イネ・タ

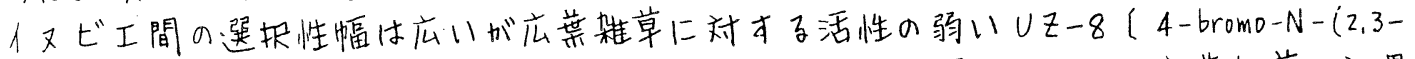

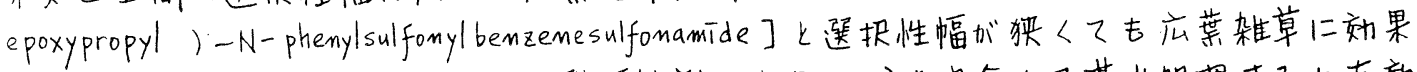

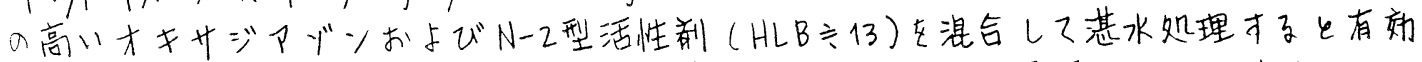

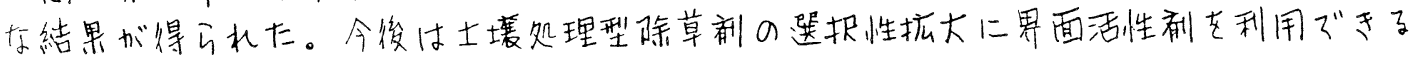
ようにさらに梗討する。 


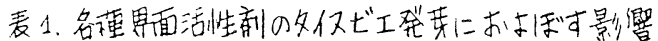

\begin{tabular}{|c|c|}
\hline 界面活性绪心型 & 発芽率 $(\%)$ \\
\hline 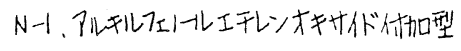 & 100 \\
\hline 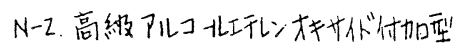 & 100 \\
\hline N-3、特姝工一札型 & 60 \\
\hline Aー1、スルホサクシネート型 & 64 \\
\hline Aー2、ジフェニルエーテル型 & 60 \\
\hline A-3.フッ素型 & 44 \\
\hline AC-1，P三1酸型 & 56 \\
\hline 慜如理 & 32 \\
\hline
\end{tabular}

界面活性剖の濃度はいずれも1000 p p m 。

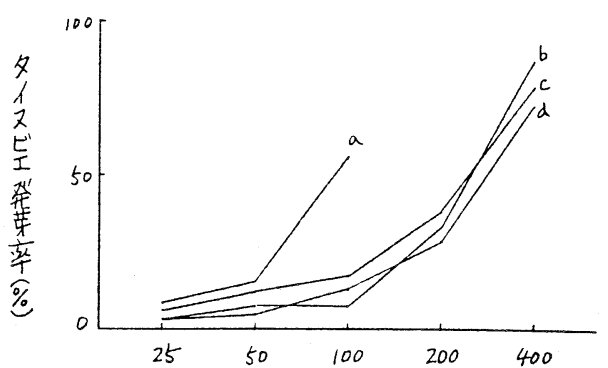

除草到㴗度( p p m )

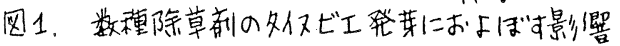
a: oxadiazon, bi nitrofen.

ci CNP. di chlomethoxymil.
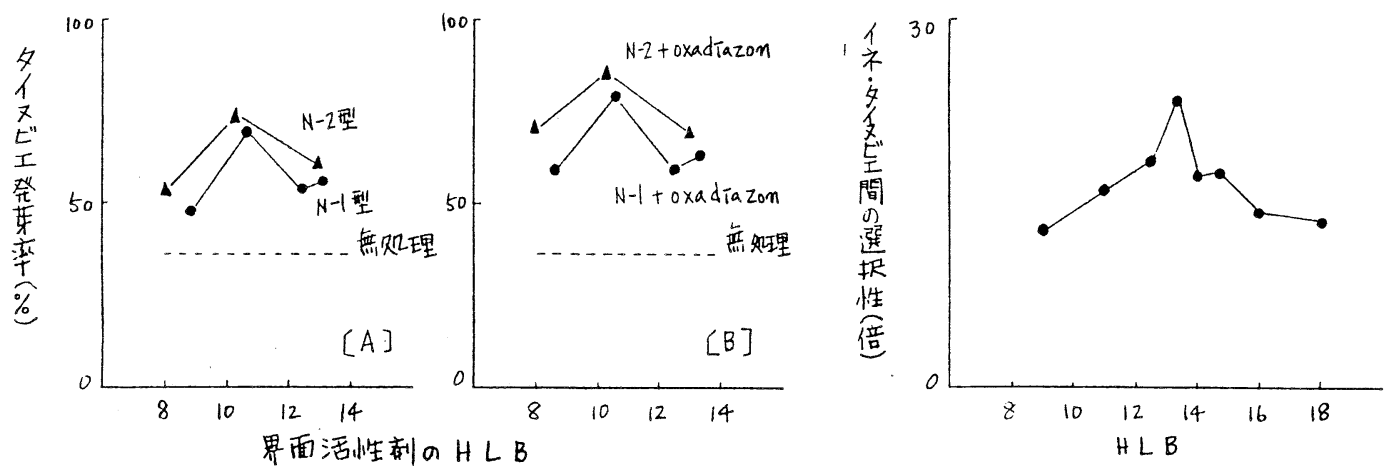

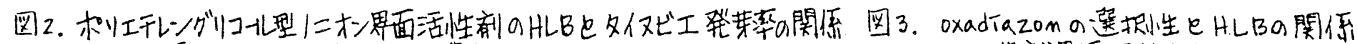

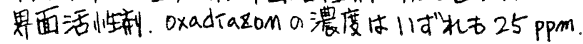
供試界面活性䛥はN型

表2. オキ甘ジアゾンとしるー8の混合による 湛水上境処理好果と人不莫害

\begin{tabular}{|c|c|c|c|c|}
\hline 萫前 & 薄量(g/10a) & 衤 & 久イ代工 & コナギ \\
\hline \multirow[t]{2}{*}{ オキサジアゾソ } & 0.5 & 0.5 & 3 & 4 \\
\hline & 1 & 1 & 4 & 5 \\
\hline \multirow[t]{2}{*}{$u z-8$} & 10 & 0 & 5 & 1 \\
\hline & 20 & 0 & 5 & 2 \\
\hline \multirow[t]{2}{*}{ 界面活性䛥 } & 100 & 0 & 0 & 0 \\
\hline & 200 & 0 & 0 & 0 \\
\hline \multirow{2}{*}{ 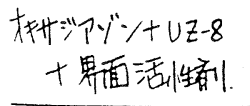 } & $0.5+10+100$ & 0 & 5 & 5 \\
\hline & $1+20+200$ & 0 & 5 & 5 \\
\hline
\end{tabular}




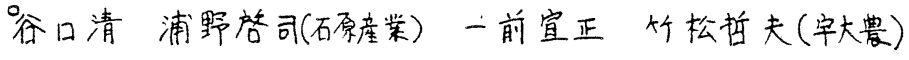

1. 目的 fluazifop-buty|\{buty| $2-\{4-(5-$ trifluoromethyl-2-pyridyloxy) phenoxy] propionate $\}$ は

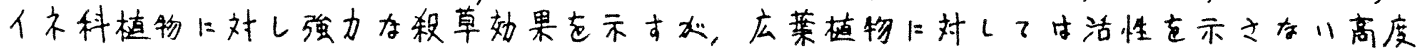
選択性、除草刺である。演者らはfluazifop-butyl と他剂と混合に上y (1) fluazifop-butyl の除草効果に及ぼす影響，(2) fluazifop-butylの除草効果発現までの期間に及ぼす影響に ついて検討したので報告する。

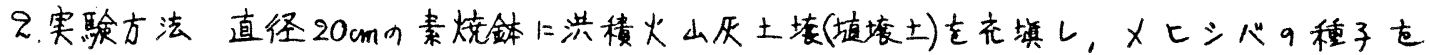

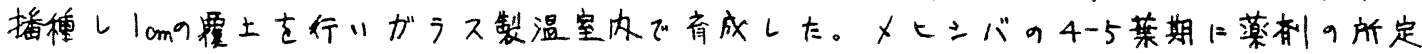

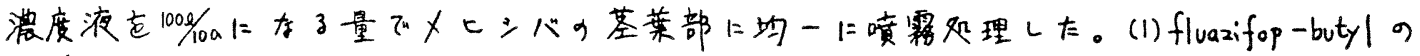

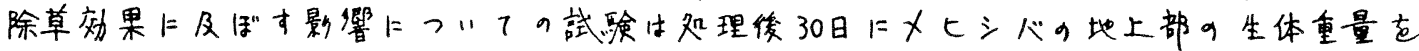
測定した。(2) fluazifop-butylの除草効果発現までの期間に及ほす影響についての試験は

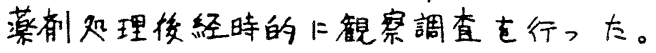

3. 结果オーキシン型结性を示す化合物は、fluazifop-butyla 刹草効果に拮抗すること 汃次前から確为られているが、今回の試験で、fluazifop-buty/と他剂と、湜合による影響 加fluazifop-butylに対し1.オーキシ型化合物のように拮抗を示す薬剂、2、大部分の薬

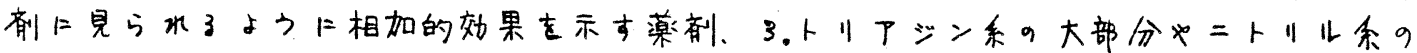

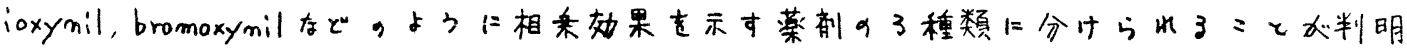
した。またト川アジン系やニトリル系の ioxymil, bromoxymiなどの相采効果を示す代合 物はfluazifop-buty/a効果発現までの期間を短くすることも判明した。

しれしトリアジン系化合物内において湜合による相来効果に大きな差加見られること 汃藻剂の吸收量の差メ゚効力差なでを考えて今後梌讨する。
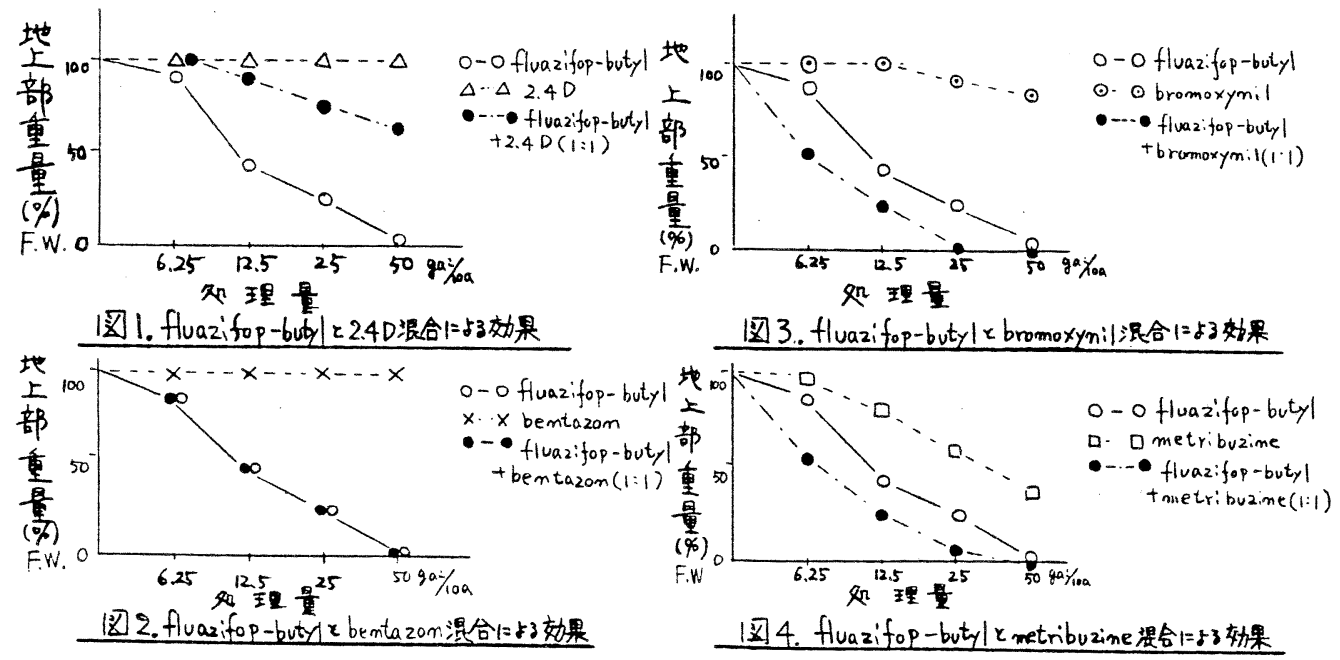
表1，fluazifop-buty|と他剂とa湜合効果

\begin{tabular}{|c|c|c|c|c|c|}
\hline 化合物 & 系統 & 湜合好果 & 化合物 & 系 統 & 湜合效果 \\
\hline 2.40 & phenoxy & - & sidurom & Urea & \pm \\
\hline$M C P$ & $"$ & - & dymrom & $"$ & \pm \\
\hline triclopyr & " & - & Sodium cyanate & imorganic & \pm \\
\hline dicamba & bem 2oic acid & - & atrazime & triazine & + \\
\hline Chloramben & $"$ & - & cyanazine & " & + \\
\hline benazolin & miscellaneous & - & metribuzine & " & + \\
\hline NAA & " & - & terbutylazine & " & + \\
\hline bialaphos & phosphorous & - & atratome & 1 & + \\
\hline acifluorfen & diphemylether & \pm & prometone & " & + \\
\hline bifemox & $"$ & \pm & terbumetone & " & + \\
\hline benthiocarb & carbamate & 土 & ametrym $_{\text {res }}$ & " & + \\
\hline Phem medipham & " & \pm & desmetrym & $"$ & + \\
\hline$S L-501$ & Phenoxy & \pm & Simetryn & $"$ & + \\
\hline propanil & amide & \pm & terbutryn & $"$ & + \\
\hline bentazom & Pyrimidine & \pm & ioxymil & nitrile & + \\
\hline limurom & Urea & \pm & bromoxymil & $"$ & + \\
\hline
\end{tabular}

混合効果判定一措抗，士相加十相采

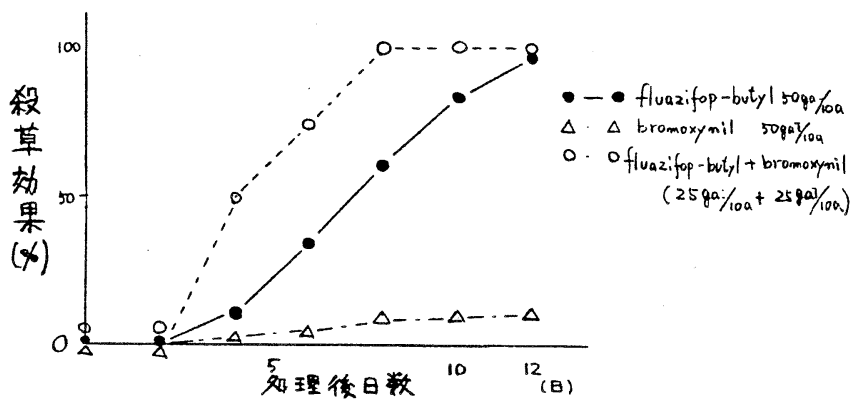

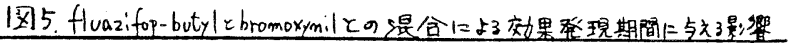

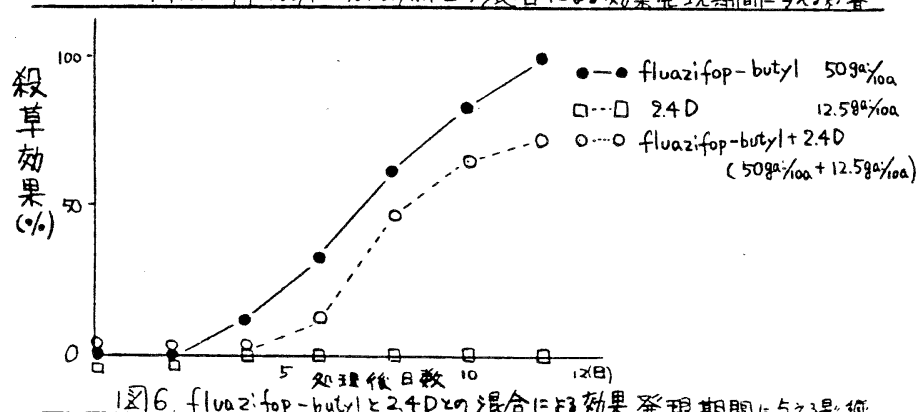


89 S-isopropyl hexahydro-1H-azepine-1-carbothioate (R-4574)に 関する研究 第3 報 R-4574の作用特性について（2）

神嵪充・富岡博実・田川害夫（中外製薬化成研）

\section{(目的)}

R-4574の雑草殺草性、およびイネ，七工間の選択性を明らかにする。

\section{(万法)}

1。杂隹草殺草性

(1). 水田雑草に対する殺草性は、屋外のコンワリートポット $(50 \times 50 \mathrm{~cm}$, 深さ45cm)試験で、 イネ移植3日後湛水土壤処理により検討した。(2). 迈理方法と効果およびイネに对

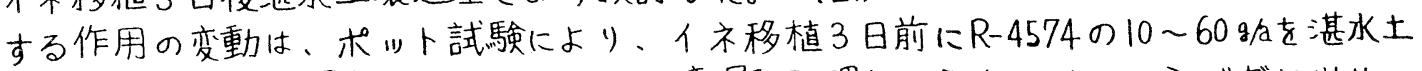
壤処理，代かき後㯰水処理，あるいは土㳖混和処理し、タイアジエ，ミズがヤツリに 对する効果、およびイネの生育を調查した。(3). ワログワイに对する効果は、ポッ 卜試験で処理時期別に5 0 \% 生育抑制薬量を求め大。(4). 水深とタイヌビ工殺草効果 は、 $0,05,1 ， 2 ， 3 \mathrm{~cm}$ の水深で、ポット試験により比較検討した。

2. イネ, 上工間選択性

(1). 処理時期と殺草力は、発芽時〜 5 し期までの雨植物に对する $50 \%$ 生育抑制薬量 で比較した。(2)、処理部位と効果は、第4龱に示した部位にR-4574 加40 g/a となるよ うに土垶混和処理を行い、作用を比較した。(3). 水耕実験により、両植物の感受性 を濃度別に比較した。(4). 两植物種子を、R-4574 の50PPm 溶液に浸漬後、経時的に 取り出して10日間水耕栽培の後、第1本葉長を测定して反応速度を比較した。

\section{(結果)}

1. 杂隹草殺草性

(1). R-4574の水田雑草に対する殺草性は、タイヌビエに効果が高く、ついでミズが ヤリリ，クログワイにカなり高い作用を示した（第、表）。（2）玑理方法と効果の 関係は、タイヌビエに对してはいずれの方法も殺草効果に变動はなかったが、土鐄混 和処理の場合、ミズガヤツリに对しやや効果功増大し、イネに对しては、高蔡量でわ ずかな生育抑制が开られた（第２表）。（3）ワログワイに对しては、3〜5し期の 処理が最も効果が高かった（第１四）。(4). 夕イヌビエに对する作用は、水深が0 〜3 cmの範囲では、3 cmの条件が最も高かった（第2困）。

2.イネ, 上工間選択性

(1). イネとヒエでは、50\%生育抑制苩量にかなりの差があり、2し期処理で最もと の幅加大きかった（第3困）。（2），処理部位とイネ，七工の感受性は、播種面より 上万に処理層がある場合、ヒエ>イネの傾向を示し、下方の場合、イネ>ヒ工の傾句 を示した（第４罒）。したがって、選択性のしつは、胚軸の伸長性と関係しているも のと考えられる。（3）、水耕法によるイネ，上工間の選択性の幅は、5〜10 p P m の場 合に最大大力った（第5四）。（4）、イネおよびヒエの第、葉伸長抑制作用は、い ずれも種子浸漬時間が長いほど大きかった。なお、最大の作用を発現するに必要な浸 漬時間は、七エの場合、24時間で、イネでは48時間以上でわった（第6 6 龱）。 


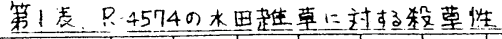

\begin{tabular}{|c|c|c|c|c|c|c|c|c|c|c|c|}
\hline 試 & \multirow{2}{*}{ 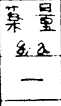 } & \multirow{2}{*}{$\begin{array}{c}917 \\
\text { ビI } \\
100 \% \\
615]\end{array}$} & \multirow{2}{*}{$\begin{array}{l}\text { マが } \\
\text { Р"y } \\
100 x \\
26] \\
\end{array}$} & \multirow{2}{*}{\begin{tabular}{|l|} 
ナ+ギ \\
$100 \%$ \\
$[6]]$
\end{tabular}} & \multirow{2}{*}{\begin{tabular}{|c|}
$P \mathbb{R}^{\prime}+$ \\
$100^{\circ} \%$ \\
{$[3.8]$} \\
\end{tabular}} & \multirow{2}{*}{\begin{tabular}{|c|} 
キカシ \\
?゙サ \\
$100 \%$ \\
$(4.3]$ \\
\end{tabular}} & \multirow{2}{*}{\begin{tabular}{|c|}
$\because "$ \\
1130 \\
$100 \%$ \\
$(12)$ \\
\end{tabular}} & \multirow{2}{*}{\begin{tabular}{|l|} 
权M \\
$100 \%$ \\
1173 \\
\end{tabular}} & \multirow{2}{*}{ 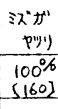 } & \multirow{2}{*}{$\begin{array}{c}707 " \\
71 \\
100 \% \\
1[15]\end{array}$} & \multirow{2}{*}{\begin{tabular}{|c|} 
רמו' \\
$100 \%$ \\
5182 \\
\end{tabular}} \\
\hline & & & & & & & & & & & \\
\hline \multirow{4}{*}{$R-4574$} & 20 & 8 & 35 & 92 & 100 & 100 & 87 & 86 & 71 & 33 & 93 \\
\hline & 30 & 1 & 23 & 85 & 98 & 103 & 87 & 75 & 63 & 21 & 80 \\
\hline & 40 & 0 & 15 & 73 & 101 & 101 & 67 & 58 & 10 & 16 & 93 \\
\hline & 50 & 0 & 16 & 57 & 100 & 88 & 56 & 29 & $\mathrm{t}$ & 6 & 103 \\
\hline
\end{tabular}

注)、1)数檤は.生体重の対無処理比で示(た。〔了:实測值(g)

2). 処理日: 昭和56年6月24日。調春日:7月24日

第2表、R-45749处理方法と効果ならル゙に依に将する菜害

\begin{tabular}{|c|c|c|c|c|c|c|c|c|c|c|c|c|c|c|c|c|}
\hline \multirow{2}{*}{ 試験区 } & \multirow{2}{*}{$\begin{array}{l}\text { 度量 } \\
(g / 2)\end{array}$} & \multicolumn{5}{|c|}{ 湛水土䢂処理 } & \multicolumn{5}{|c|}{ 代カき後濁水処理 } & \multicolumn{5}{|c|}{ 土壤混和処理 } \\
\hline & & \begin{tabular}{|c|}
817 \\
c"I \\
\end{tabular} & 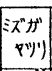 & $\begin{array}{l}1 \star \\
\text { 茥丈 }\end{array}$ & 分調 & $\begin{array}{l}\text { 查 } \\
\text { 若害 }\end{array}$ & $\begin{array}{l}\text { 917 } \\
\text { ビI }\end{array}$ & 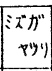 & $\begin{array}{c}1 \\
+ \\
\end{array}$ & 3 & 害 & ビ'I & 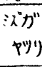 & $\begin{array}{l}1 \lambda \\
\text { 丈 }\end{array}$ & 甿 & $\begin{array}{l}\text { 查 } \\
\text { 害 }\end{array}$ \\
\hline & - & $\begin{array}{l}100 x \\
{[8.3]} \\
\end{array}$ & $\begin{array}{l}100 \% \\
{[8.2]} \\
8\end{array}$ & $\begin{array}{l}100 \% \\
{[5600]}\end{array}$ & $\begin{array}{l}100 \% \\
(9.5) \\
\end{array}$ & - & 100 & 100 & 100 & 100 & - & 100 & 100 & 100 & 100 & - \\
\hline \multirow{5}{*}{$R-4574$} & 10 & 5 & 49 & 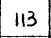 & 118 & - & 7 & 38 & 104 & 126 & - & 4 & 51 & 103 & 100 & - \\
\hline & 20 & 0 & 37 & 10 & 124 & - & & 24 & 5 & 134 & 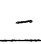 & 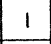 & 12 & 98 & 107 & - \\
\hline & - & 0 & 22 & 102 & 122 & - & 0 & 23 & 104 & 116 & - & 0 & 11 & 101 & 22 & - \\
\hline & 40 & 0 & 20 & 22 & 112 & - & 0 & 2 & 08 & $12^{\circ}$ & - & 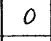 & 9 & 100 & 01 & - \\
\hline & 60 & 0 & 10 & 106 & 112 & $1-$ & 0 & 20 & 100 & 105 & - & 0 & 4 & 87 & 86 & \pm \\
\hline
\end{tabular}

注) 1)数值は生体重の对筫処理比で示した。〔]：实測值

2) 处理日: 昭和55年1月8日，謂查日：2月7日。

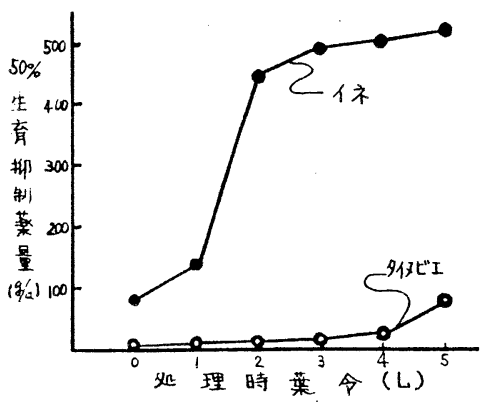

第3四、依，上工の処理時葉令KR-4574 の50\%生育抑制菜量

注) 調查は迈理淩15日目に实施

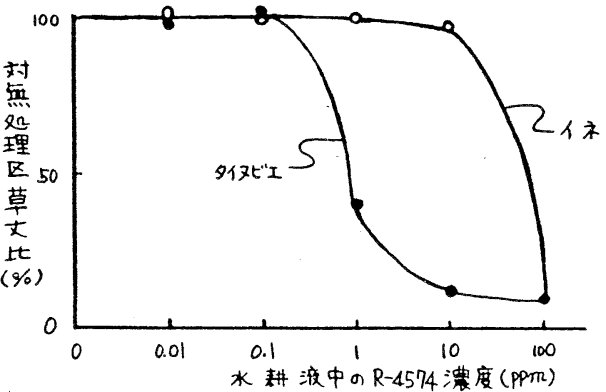

第5因、R-4574のイネ，上工間選択性

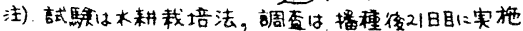

注)処理時期

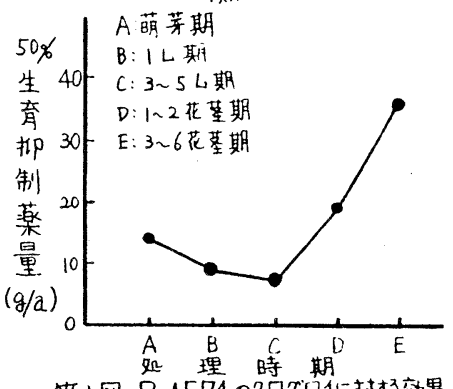

第1国、R-4574のフロプ优村る効果 注)調查は迈理後31日目に实施

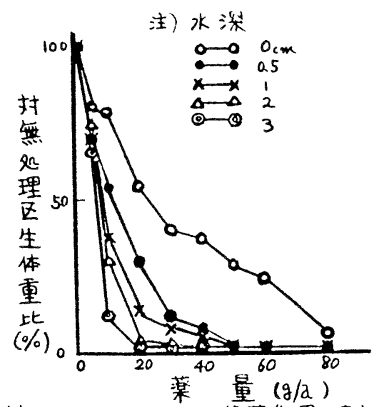

第2因、R-4574a大工殺草作用下なよ ばす水深の影柿

注)調查は処理後33日目に实杝

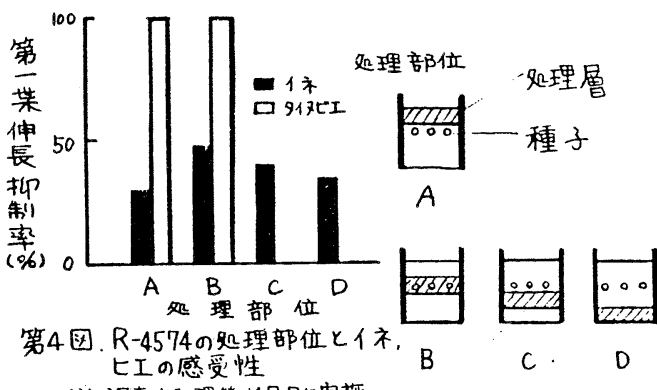

注) 調査は処理淩14日目に实施

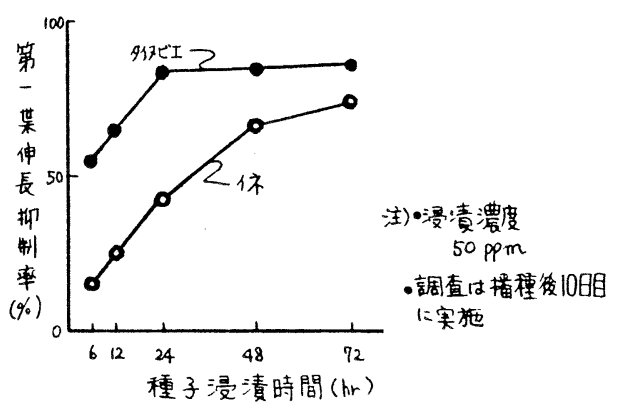

第6因、R-45749処理時間飞効果 


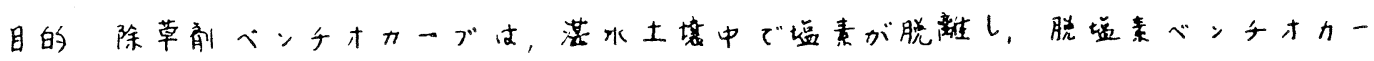

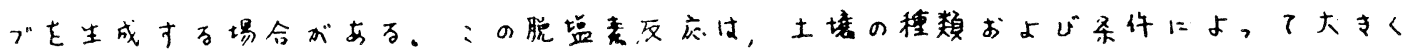

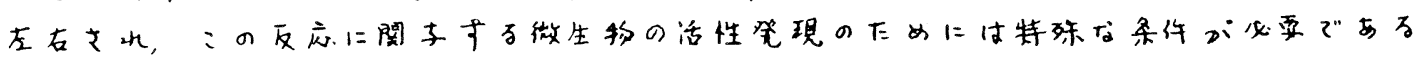

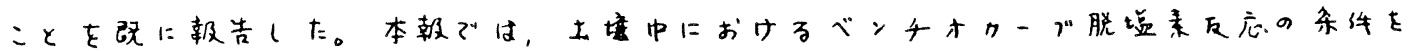

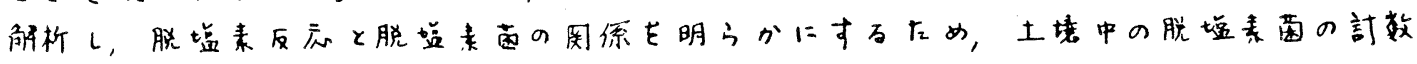
法を破立し，认の消舅をし々でE。

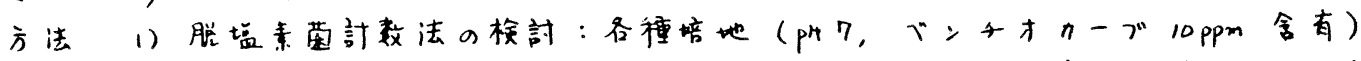

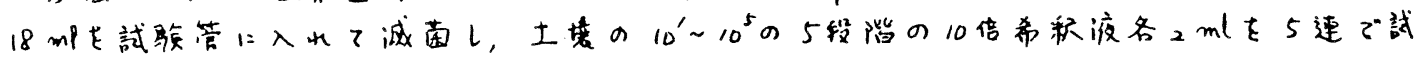

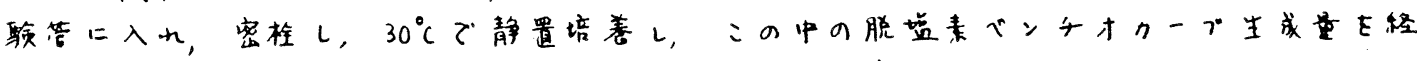

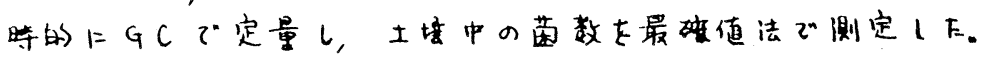

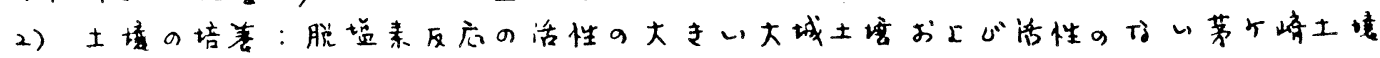

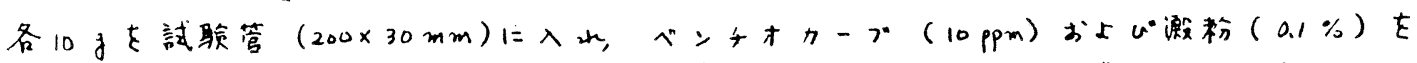

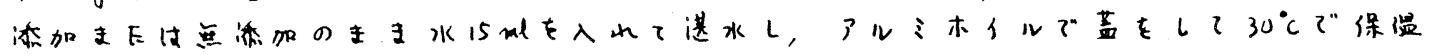

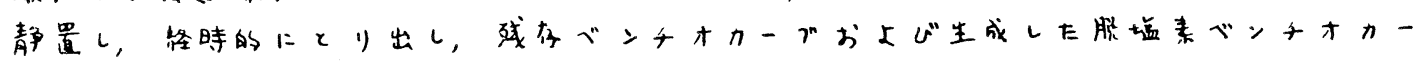

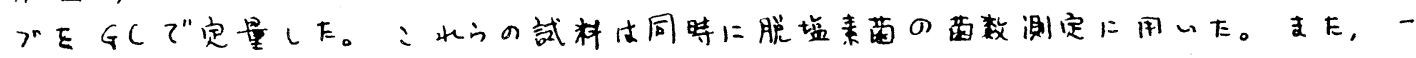

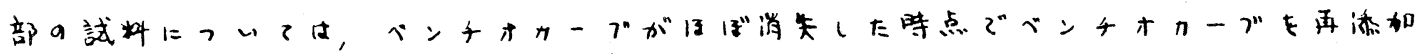

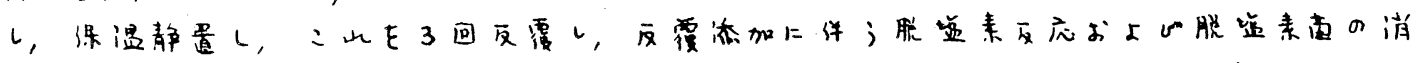

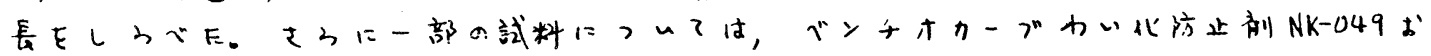

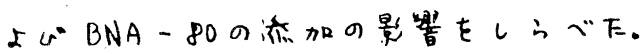

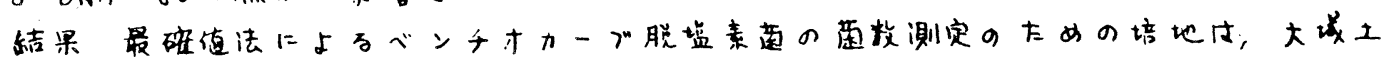

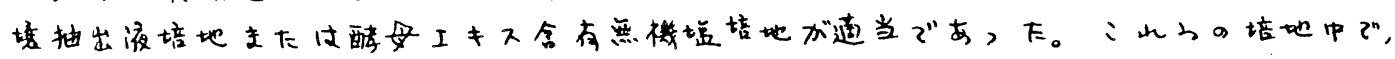

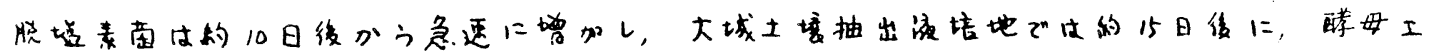

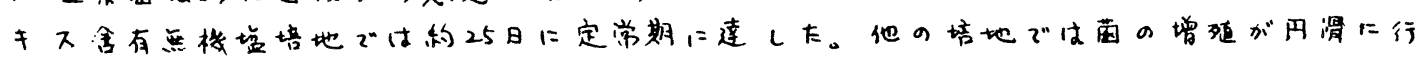

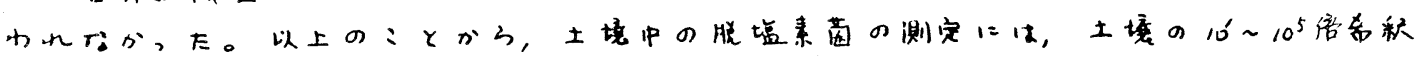

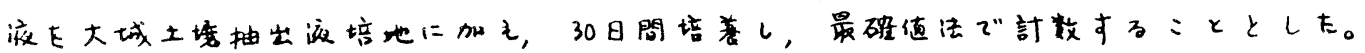

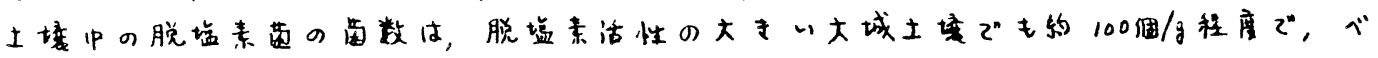

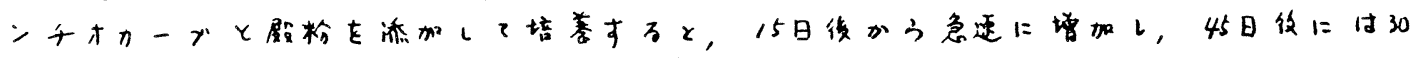

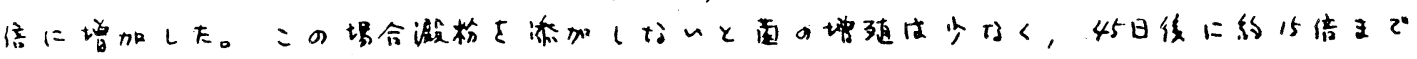

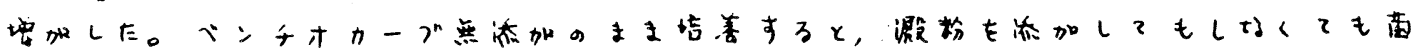

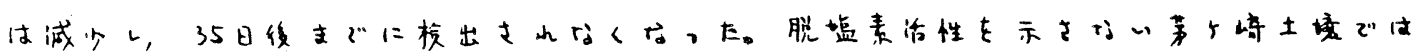

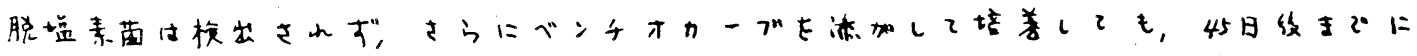

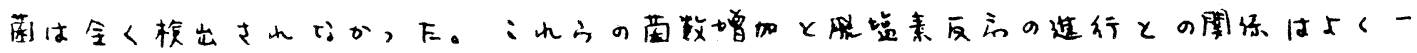
致し $E$ (Fig. 3)。

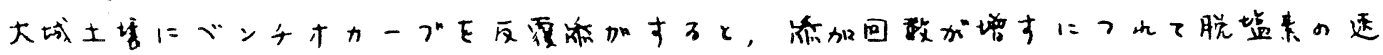

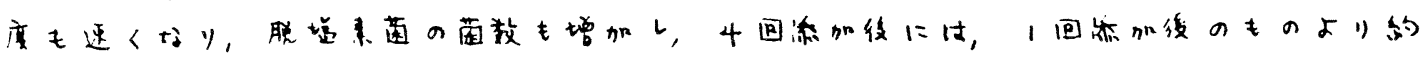
5 结に坮 $\pi^{2} L(F$ Fig, 4)。 


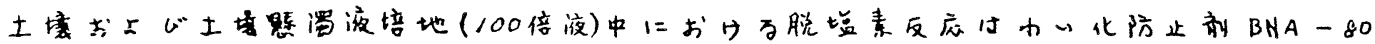

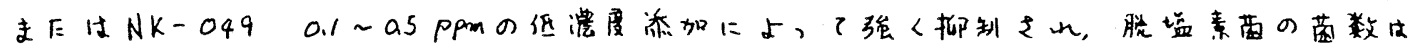

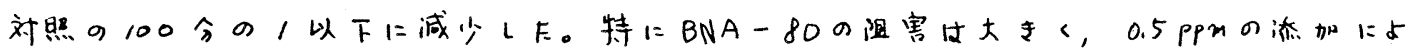

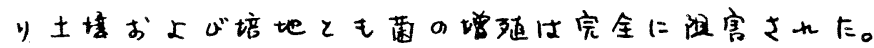
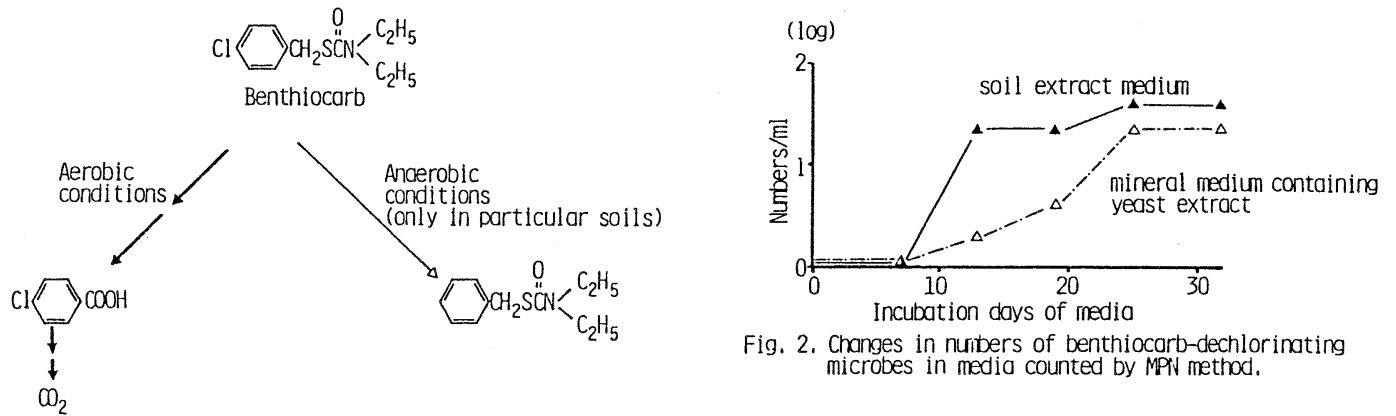

Fig. 2. Changes in nuribers of benthiocarb-dechlorinating microbes in media counted by MPN method.

Fig. 1. Degradation pathways of benthiocarb in soils
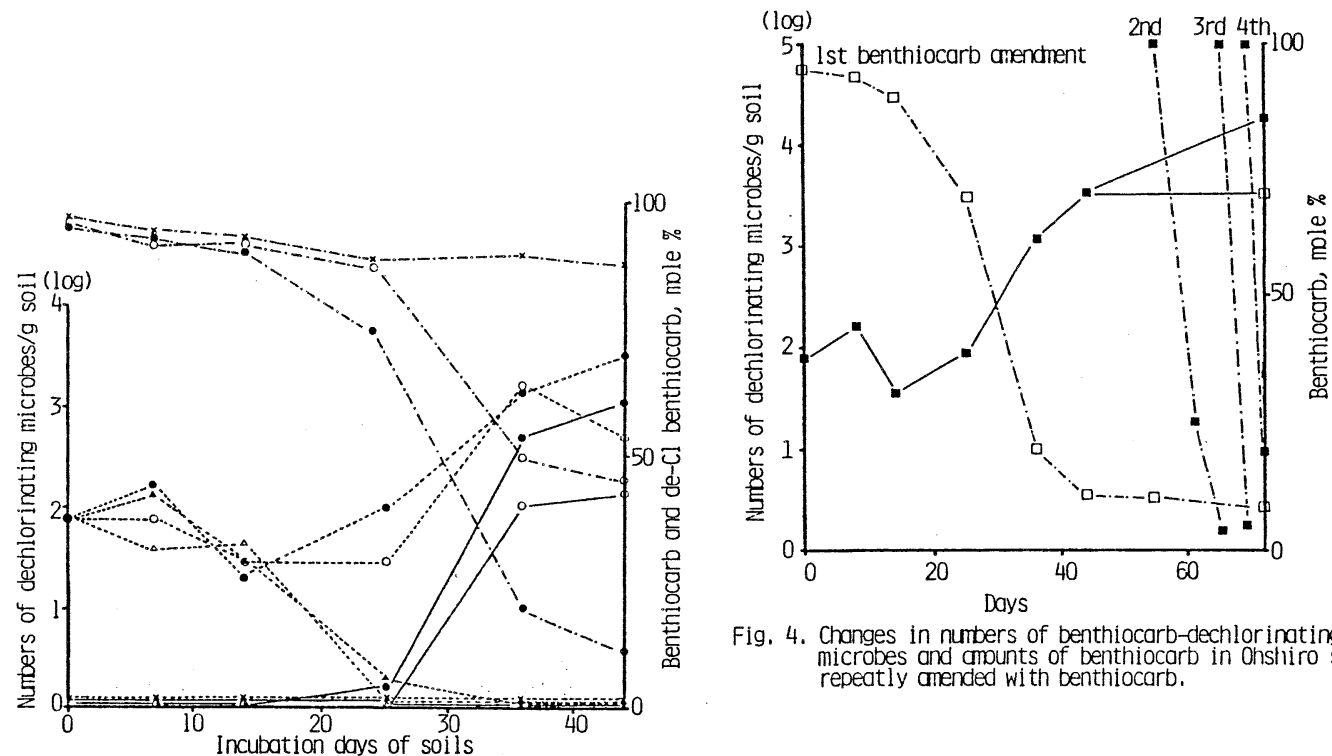

Fig. 4. Changes in numbers of benthiocarb-dechlorinating microbes and amounts of benthiocarb in Ohshiro soil repeatly amended wi th benthiocarb.

Fig. 3. Changes in numbers of benthiocarb-dechlorinating microbes and amounts of benthiocarb and dechlorinated benthiocarb in soils.

-.... : numbers of microbes $\triangle$ : Ohshiro soil

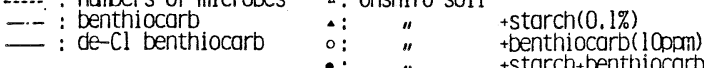

: : Chikasaki soi +starch+benthiocarb

Table 1. Numbers of benthiocarb-dechlorinating microbes in soll and soll-suspended medium at 30 days after amenchent with awarfing preventives.

\begin{tabular}{|c|c|c|c|c|c|c|}
\hline & \multicolumn{6}{|c|}{ numbers of benthiocarb-dechlorinating microbes } \\
\hline & \multirow{2}{*}{$\begin{array}{l}\text { non- } \\
\text { cmendment }\end{array}$} & \multicolumn{2}{|c|}{ NK- 049} & \multicolumn{3}{|c|}{ BNA-80 } \\
\hline & & 0.2 & 0.5 & 0.1 & 0.5 & $\overline{\mathrm{ppm}}$ \\
\hline soil & $4.9 \times 10^{3}$ & & $3.6 \times 10$ & & $<180$ & \\
\hline medium & $1.7 \times 10^{4}$ & $1.7 \times 10^{2}$ & $2.3 \times 10$ & $1.7 \times 10^{2}$ & $<18$ & \\
\hline
\end{tabular}

